\title{
RESISTENSI MASYARAKAT TERHADAP ELITE BARU PASCA-HELSINKI DI ACEH
}

\author{
Iromi Ilham \\ iromi_vlx@yahoo.com \\ Lembaga Seuramoe Budaya \\ Abstract
}

The reconcilement of Helsinki became the gateway of the Acehnese transformation which has implicated to the social and political change in Aceh. One other thing is the emergence of former GAM fighter as the new Acehnese elite. The collective trauma of the Aceh community led by "outsiders" before Helsinki treaty years ago made the people of Aceh want to leave hope to the awaknanggroe. However, over the time, as if the history of the past was repeated. People feel the social imbalance that practiced by the new elite who ever once existed as "justice fighters". The failure of reciprocity practiced by the elite as a form of responsibility to the people causes the resistance from society, whether it is in an insinuation or in the open pattern. This is the main study in this paper. Finally, the propaganda Meunyoe keun ie, mandum leuhob.Meunyoeu keun droe teuh, mandum gob which was once massively accepted, has expressed to a new antithesis; Nibak ngeun ie, mangat ngeun leuhob, nibak ngeun droeu teuh, mangat that ngeun gob.

Keywords: GAM, New Elite, Resistance, Aceh 


\section{PENDAHULUAN}

Suatu ketika, saat jalan-jalan sore di wilayah Aceh Besar, saya terjebak hujan dan terpaksa harus mencari tempat berteduh. Warung kopi adalah pilihan bijak disaat kondisi untuk meneruskan perjalanan sudah bukan pilihan. Di pintu masuk warung tersebut, terlihat seorang pria dengan postur tubuh atletis. Gayanya yang nyeleneh sangat kontras dengan penampilannya yang "elegan". Kemeja kotakkotak dengan paduan jeans bermerek yang dikenakan, lebih dari cukup untuk menutup identitas dirinya yang sebenarnya. Walau pakaian sudah terlihat sedikit lusuh, tetapi mampu membuat siapa pun yang asing di kawasan itu, seperti saya, ragu untuk mengatakan "ada yang tidak beres dengan orang itu".

Tidak lama kemudian, ia berjalan mendekati tempat saya duduk. Saat berhadapan dalam jarak satu meter, ia berbicara menggunakan bahasa tubuh yang mengisyaratkan meminta saya untuk memberinya sebatang rokok. Ia menunjuk ke kotak putih bertuliskan "Marlboro" yang dari tadi terletak indah di samping secangkir kopi yang masih mengepulkan asap. Lantas, saya menyuguhkan isi kotak tersebut. Setelah mengambil sebatang, ia langsung berlalu tanpa mengucap sepatah kata pun. Gelagat "kebingungan" saya tercium oleh seorang pria paruh baya yang duduk tidak jauh dari tempat saya.

Sejurus kemudian, pria itu -yang kemudian saya tahu bernama Yusuf-menghampiri saya dan kami terlibat dalam obrolan singkat. Di sela-sela itu, Yusuf berucap "adak pih $k a$ meunan, nyan pejuang awai...”,1 sembari telunjuk kanannya diarahkan ke pemuda yang sempat membuat saya tersenyum sendiri.

Di desanya, pemuda "pejuang" itu biasa disapa Wa Ang. Dulu, ia adalah mantan kombatan GAM yang berjuang untuk kemerdekaan

1 Terjemahan: "Walaupun penampilannya begitu, dia adalah mantan pejuang (GAM) dulu". 
Aceh. Meskipun Wa Ang bukan tokoh sentral dalam perjuangan, namun keberadaannya bisa dikatakan sangat penting. Ia adalah orang yang pertama memberi informasi kepada anggota GAM lainnya jika TNI sudah mulai bergerak masuk untuk menyisir wilayah pedalaman untuk operasi. Sehingga anggota GAM lainnya bisa mempersiapkan diri untuk menghadapi segala kemungkinan yang akan terjadi. Dalam istilah lokal, profesi seperti Wa Ang sering disebut dengan istilah "awak mat radio" 2.

Yusuf melanjutkan bahwa keberadaannya sebagai orang yang terlibat dalam institusi GAM tercium aparat keamanan sehingga pernah mendapat perlakuan yang tidak manusiawi dari pihak aparat Indonesia yang berujung pada gangguan mental. Namun kondisinya saat ini sudah lebih parah lagi disebabkan tidak terurus secara medis. Pasca damai, ia termasuk kombatan yang tidak mendapat pehatian khusus dari para petinggi GAM lainnya di wilayah tersebut. Ia hanya mendapatkan satu unit mesin perontok padi sebagai kompensasi dari perundingan damai. Selebihnya, ia tidak mendapat apa-apa layaknya teman-teman pejuang lainnya yang sebagian besar sudah suskses secara ekonomi.

Semakin hari, Wa Ang semakin tersisihkan dari kawan seperjuangannya, karena itu pula membuat gangguan mentalnya semakin parah. Ia memang tidak pernah menggangu orang lain. Kebiasaannya hanya meminta rokok dari siapa saja yang ada. "Dulu saat masih di hutan, mereka (GAM) masih bisa sebatang rokok dihisab bersama, namun sekarang mereka saling sikat dalam memperebutkan uang yang diberi Jakarta" ketus Yusuf diakhir pembicaraan.

2 Orang yang memegang saluran komunikasi radio HT (handy Talky) dan tugasnya sebagai informan. Pada saat konflik, biasanya mereka bertugas untuk memantau keadaan dan memberi informasi jika ada TNI atau Aparat keamanan yang masuk untuk menyisir keberadaan GAM. Mereka tinggal bersama masyarakat atau di tempat keramaian supaya mudah mendapatkan informasi jika ada pihak musuh yang mendekat. 
"Badai pasti berlalu", begitu ungkap Berlian Hutahuruk dalam tembang lawasnya. Begitupun badai yang membuat saya harus menepi. Kemudian saya pamit dan melanjutkan perjalanan sore itu yang kian syahdu ditemani aroma debu yang basah bersebab hujan.

Kisah Wa Ang bisa jadi salah satu dari sekian banyak cerita pilu yang dirasakan mantan pejuang dan masyarakat Aceh yang pernah memiliki pengalaman hidup dalam dunia yang dipenuhi peluru. Lakon perang bagi masyarakat Aceh seakan sudah seperti konstruksi budaya generik yang turun-temurun dari generasi ke generasi. Perang, senjata, tembakan, darah dan segala sesuatu yang berbau konflik sudah begitu akrab. Meskipun damai telah menyapa Aceh, sayup-sayup juga masih terbaca di lembaran surat kabar lokal jika senjata masih saja menyalak dan memakan korban. Hanya saja, suara tembakan dan darah yang mengalir pasca Helsinki, tidak lagi bermuara pada konflik politik GAM dan Pemerintah Pusat, tetapi dianggap sebagai kejadian "kriminalitas biasa". Meski tidak bisa dipungkiri, beberapa peluru yang melejit, tetap saja meninggalkan selongsong yang berbau politik.

Kini, damai telah tersemai di bumi tanoeh rincong. Implikasi perdamaian termanifestasi dalam perubahan konstelasi sosio-kultural dan sosio-politik masyarakat Aceh. Tidak berlebihan jika MoU Helsinki dianggap sebagai titik kulminasi lahirnya peradaban baru. Sebuah peradaban yang sarat pada agenda-agenda transformasi, baik yang bersifat analitis, historis, maupun praktis. 3 Salah satu agenda transformasi yang terlihat jelas hari ini adalah munculnya elite baru Aceh dari kalangan mantan pejuang GAM. Elite baru yang dimaksud adalah sekelompok individu yang berafiliasi dengan GAM, baik secara langsung maupun tidak langsung yang sudah berhasil mencapai kedudukan dominan dalam kehidupan masyarakat Aceh, baik itu memiliki kekuasaan, kekayaan, maupun kehormatan. Evers dan

3 Irwan Abdullah, 'Tantangan Pembangunan Ekonomi dan Transformasi Sosial: Suatu Pendekatan Budaya", Jurnal Humaniora, Vol, XIV, edisi 3, 2002, hal. 260-270. 
Schiel menyebutnya sebagai kelompok-kelompok strategis yang kini memiliki fungsi untuk perkembangan politik, reformasi ataupun revolusi dalam masyarakat. 4

Peran yang dominan dan akses yang terbuka terhadap pusatpusat kekuasaan, memunculkan beragam kekhawatiran dari berbagai kalangan di Aceh. Misalnya apa yang diungkapkan oleh pengamat politik, Fachry Ali, dalam seminar nasional "Studi Sosiologi Agama dan Persoalan Sosial Keagamaan di Aceh" yang digelar Fakultas Ushuluddin dan Filsafat Universitas Islam Negeri (UIN) Ar-Raniry. Menurutnya, komunitas elite baru di Aceh yang merupakan produk MoU Helsinki bukan lahir dari landasan profesionalisme sejati, sehingga kalangan "super elite" baru di Aceh akan melahirkan kelas masyarakat konsumtif di mana perputaran uang yang tidak sehat begitu kentara di kalangan elite tersebut, hal ini dikarenakan sebagian pendapatan dikuasai oleh kelas masyarakat tersebut, Fachry Ali menyebutnya sebagai "kaum romantisme masa lalu".5

Kekhawatiran Fachry Ali menjadi kenyataan dengan melihat beragam gejolak dan resistensi yang muncul dari kalangan akar rumput. Kesejahteraan yang menjadi harapan masyarakat Aceh ketika sudah di bawah kuasa awak nanggroe masih dipertanyakan dan diperdebatkan oleh beberapa pihak. Kala Aceh masih bergolak, masyarakat Aceh di berbagai pelosok bersatu padu "berjuang" bersama GAM, sementara saat ini, ketika perdamaian telah tercipta, GAM dianggap melupakan bantuan rakyat di masa konflik.

Padahal, efek dari membantu perjuangan adalah mendapat Shock terapy dari pihak TNI, semisal pembunuhan kilat, penangkapan, pembunuhan sewenang-wenang, penyiksaan tanpa pengadilan, dan pelecehan seksual. Sasaran perlakuan tersebut tidak

\footnotetext{
4 H. D Evers \& Schiel, T., Kelompok-Kelompok Strategis: Studi Perbandingan tentang Negara, Birokrasi, dan Pembentukan Kelas di Dunia Ketiga (Jakarta: Yayasan Obor Indonesia, 1990).
}

5 http://aceh.tribunnews.com/2014/08/21/generasi-helsinki-rentan-tersingkir 
hanya bagi anggota GAM, tetapi juga bagi masyarakat yang dicurigai sebagi teman, kerabat, atau saudara dari anggota pejuang yang dianggap pernah memberi bantuan terhadap perjuangan GAM.6 Dalam catatan Aspinal, thirty-three thousand people lost their lives violently during the twenty-nine years of the conflict. 7

Pada titik inilah muncul gesekan dan resistensi yang dijewantahkan dalam berbagai bentuk. Terlihat kekecewaan di sana ketika harapan dan kenyataan tidak berjalan selaras. Kisah Wa Ang, sang "pejuang" yang terbuang itu bisa menjadi batu loncatan akan hadirnya tulisan ini. Dalam bahasa yang sederhana, tulisan ini hendak mengkaji tentang bagaimana pola resistensi masyarakat Aceh terhadap elite politik baru yang muncul pasca MoU Helsinki. Secara teoritis, diskusi ini diharapkan menjadi bagian kecil dari bacaan ilmiah yang kemudian bisa menambah wawasan keilmuan, terkhusus tentang perubahan fenomena sosial-budaya dan politik di Aceh pasca Helsinki yang dilihat dari kaca mata antropologis. Selain itu, kajian ini juga diharapkan dapat memberikan manfaat praktis, di mana bisa menjadi "cermin reflektif" bagi para elite baru Aceh dalam melihat perubahan-perubahan dan respon masyarakat ketika Aceh sudah dalam genggaman awak droe .

\section{METODE}

Saya tidak memberikan batasan geografis yang kaku dalam kajian ini karena lokus utamanya adalah bagaimana menemukan pola resistensi masyarakat Aceh terhadap elite baru. Ketika saya mengunjungi banyak tempat di Aceh, segala informasi dan hasil observasi empiris yang menurut saya relevan dengan kajian ini, maka akan menjadi data yang kemudian dianalisis secara deskriptif

6 M. I. Sulaiman, Aceh Merdeka: Ideologi, Kepemimpinan, dan Gerakan (Jakarta: Pustaka AlKausar, 2000).

7 E. Aspinall, 'The Construction of Grievance: Natural Resources and Identity in a Separatist Conflict”, Journal of Conflict Resolution, Volume 51, edisi 6, 2007, hal. 950-104. 
kualitatif. Namun demikian, kebanyakan data yang disajikan dalam tulisan ini adalah hasil pengamatan partisipatif di wilayah Kota Banda Aceh dan Aceh Besar. Banda Aceh, sebagai ibukota Provinsi Aceh, adalah kota yang heterogen dan menjadi tempat berkumpulnya manusia dari berbagai penjuru dan dari berbagai lapisan kelas masyarakat, termasuk juga kaum elite baru Aceh.

Sebagai sebuah kajian dalam ilmu humaniora, tentu saja penelitian ini bersifat kualitatif. Karena itu, teknik pengumpulan data yang dianggap relevan adalah observasi partisipatif (participant observation), wawancara mendalam (in-depth interview) dan juga wawancara secara terbuka. Selain itu, saya juga melakukan studi kepustakaan (library research) melaui kajian literatur-literatur yang dianggap relevan dengan kajian ini. Pengamatan langsung yang melibatkan peneliti hadir bersama subjek penelitian dianggap perlu untuk mencermati fenomena empiris yang terjadi di masyarakat. Wawancara mendalam dimaksudkan untuk mengungkap hal-hal yang tidak terlihat dalam pengamatan sehingga kita bisa memperoleh pemahaman (verstehen). Dalam menetapkan informan, saya menggunakan sistem purposive sampling dan snowball sampling.

Saya juga berusaha mendapatkan data melalui studi kepustakaan. Hal ini dianggap penting untuk memperoleh data sekunder dengan mengkaji bermacam sumber tertulis, misalnya laporan penelitian, artikel, jurnal ilmiah, surat kabar, dan buku-buku yang berkaitan dengan topik kajian ini. Selanjutnya fakta-fakta lapangan yang relevan dengan tema penelitian akan dianalisis secara deskriptif interpretatif hingga tiba pada sebuah kesimpulan akhir penelitian. Namun demikian, penelitian ini tidaklah bermaksud untuk menciptakan sebuah kesimpulan umum (law generalization) karena studi antropologi lebih kepada melakukan sebuah kajian refleksi. 


\section{HASIL DAN PEMBAHASAN \\ Resistensi dan Pembangkangan Aceh}

Dalam masyarakat Aceh, implikasi sosial dari kehadiran elite baru adalah menciptakan kelas menengah baru dan terjadinya perubahan gaya hidup yang akhirnya banyak muncul gesekangesekan, baik antara sesama kaum elitis, maupun kalangan akar rumput dengan kaum elitis. Pergesekan dan ketimpangan tersebut melahirkan beragam bentuk resistensi di masyarakat.

Dalam menjelaskan fenomena ini, saya merujuk pada konsep resistensi James Scott. Menurutnya, resisten merupakan sebuah tidakan perlawanan (resistance) yang memuat tindakan-tindakan yang dilakukan oleh kaum-kaum kalah yang bertujuan untuk mengurangi atau menolak klaim dan tindakan yang dibuat oleh kelas atas. Pola resistensi bisa diwujudkan dengan perilaku menyerobot pekerjaan, makanan, sewa dan upah, perilaku pura-pura baik, bergosip, menyindir, menjatuhkan nama baik, mencuri, dan juga mengkritik melalui karya sastra.8

Pun demikian, resistensi juga terjadi dalam kehidupan masyarakat Aceh saat ini terhadap elite yang sedang berlangsung. Bentuk resistensi dijewantahkan dalam beberapa varian, pertama, resistensi dalam bentuk insinuasi yang dipraktekkan melalui perilaku menjatuhkan nama baik, menggosip di belakang dan juga menyindir. Para penggosip kerap menghindari membicarakan secara terbuka karena alasan keamanan dan keselamatan. Kedua, sikap resistensi yang dilakukan secara terang-terangan, misalnya sindiran yang diciptakan melalui desain yang terdapat di baju atau dengan memunculkan berbagai "meme" yang bernada menyindir dan mengejek di media sosial.

8 J. Scott, Senjatanya Orang-Orang yang Kalah: Bentuk Perlawanan Sehari-hari Kaum Tani (Jakarta: Yayasan Obor Indonesia, 2000). 
Dalam hal ini, konsep resistensi Scott saya padukan dengan konsep yang ditawarkan Tedd Robert Gurr. Sebagaimana dijelaskan Manan dalam bukunya Gerakan Rakyat Melawaan Elite, Gurr menjelaskan konsep resistensi melalui teorinya Relative Deprivation. Konsep dasar Gurr adalah deprivation (perampasan). Menurutnya, resistensi lahir jika seseorang merasa sesuatu yang sepantasnya menjadi haknya atau harga dirinya dirampas oleh orang lain. Dalam artian, konsep relative deprivation adalah adanya "kesenjangan antara nilai yang diharapkan (value expectation) dengan kapabilitas untuk meraih nilai (value capabilities)". Definisa "nilai" menurut Gurr adalah "suatu kejadian, barang dan kondisi yang diinginkan oleh manusia untuk dimiliki". Nilai ekspektasi adalah "benda dan kondisi hidup yang orang-orang percaya bahwa mereka sebagai pemilik yang sah". Dan nilai kapabilitas adalah "benda dan kondisi yang menurut mereka mampu untuk memperoleh atau memeliharanya, disepakati harta sosial tersedia untuk mereka". Lebih lanjut, Gurr membagi tiga jenis nilai, yaitu: 1) nilai kesejahteraan (welfare values), dimana nilai ini berupa benda fisik yang yang dibutuhkan untuk realisasi diri. Ia berkaitan dengan sesuatu yang bernilai ekonomis dan keleluaaan untuk aktualisasi diri; 2) nilai kekuasaan (power values), nilai ini berkaitan dengan kemampuan mempengaruhi orang lain atau menangkal campur tangan orang lain yang tidak diinginkan; 3) nilai interpersonal (interpersonal values), yaitu kepuasan psikologis yang diperoleh dari interaksi tidak resmi dengan kelompok lain yang ditandai oleh status, komunalitas dan koherensi ide".9

Jika menyandingkan teori Gurr dengan konteks Aceh, saya melihat bahwa "perampasan" yang terjadi adalah di wilayah "nilai kesejahteraan" dan "nilai interpersonal". Kesejahteraan yang kerap dijanjikan oleh elite saat ini tak kunjung dirasakan oleh masyarakat kelas bawah. Sementara pada tataran "nilai interpersonal", ada semacam ketidakpuasan publik terhadap perubahan secara signifikan dalam kehidupan kelompok mantan GAM, baik secara ekonomi

9 M, Manan, Gerakan Rakyat Melawaan Elite (Yogyakarta: Resist Book, 2005). 
maupun politik. Ketidakpuasan (discontent) dalam masyarakat kemudian dimanifestasikan dalam bentuk kemarahan, kejengkelan, ataupun aksi-aksi kekerasan. Semuanya tergantung pada kedalaman rasa perampasan tersebut. Kadar ketidakpuasan akan berkurang dan meredam bila tersedia sarana untuk menyalurkannya yang disebut "value opportunities". Apabila saluran value opportunities tidak pernah ada, maka tidak menutup kemungkinan, ketidakpuasan tersebut bermetamorfosis menjadi pemberontakan yang menggunakan jalur kekerasan, kekacauan, konspirasi, ataupun perang. Jika reaksi ketidakpuasan semakin meningkat, maka akan melahirkan pemberontakan yang lebih terarah dan sistematis, dan sasarannya lebih terarah ketika sekelompok orang semakin sadar tentang siapa dan apa yang menyebabkan rasa tidak puas itu muncul.10

\section{Pola Resistensi Masyarakat Aceh terhadap Elite Baru}

Sejatinya, setiap masyarakat terbagi dalam dua katagori yang luas, pertama, sekelompok minoritas yang memiliki kemampuan sehingga menduduki posisi sebagai pemerintah; dan kedua, kelompok massa mayoritas yang menjadi objek yang diperintah.11 Andrain mengutip pendapat ilmuan politik Italia Gaetano Mosca (1858-1941) menjelaskan bahwa distribusi kekuasaan politik dalam masyarakat sebagai berikut:

Di semua masyarakat... muncul dua kelas rakyat -kelas yang berkuasa dan kelas yang dikuasai. Kelas pertama, selalu lebih sedikit jumlahnya, menjalankan semua fungsi politik, memonopoli kekuasaan, dan menikmati sejumlah keuntungan yang dibawa oleh kekuasaan, sementara yang kedua, jumlahnya lebih banyak, diarahkan dan dikendalikan oleh

10 Ibid.

11 SP Varma, Teori Politik Modern (Jakarta: PT Raja Grafindo Persada, 2010). 
yang pertama, melalui suatu cara yang kadang-kadang sedikit banyak bersifat sah, kadang-kadang sewenang-wenang dan keras. 12

Keberadaan kaum elite tidak selamanya bersifat mutlak. Artinya, selalu mengalami perubahan-perubahan atau dalam bahasa Pareto disebut dengan sirkulasi elite. Dalam hal ini, kita bisa melihat adanya proses sirkulasi elite yang terjadi di Aceh pasca Helsinki. Para aktor yang menjadi elite sebelum lahirnya MoU Helsinki adalah individu yang dianggap berafiliasi dengan pemerintahan Republik Indonesia. Kehadirannya dianggap sebagai perpanjangan tangan negara yang lebih mengakomodir kepentingan pemerintah pusat ketimbang merealisasikan kepentingan rakyat di daerah. Lantas, ketika MoU Helsinki tercipta, maka berpengaruh pada perubahan struktur politik, di mana para elite GAM melihat sebuah peluang politik untuk "menggeser" elite-elite sebelumnya. Kondisi ini menjadi "angin segar" bagi mayoritas Masyarakat Aceh kala itu.

Namun dalam perjalanannya, angin segar yang diharapkan juga tak kunjung berhembus. Ibarat kata orang Aceh, watee di laôt sapu pakat, troeh u darat laén keunira. Ungkapan simbolik tersebut ditujukan kepada seseorang atau sekelompok orang yang melupakan apa yang telah diucapkan atau mengkhianati janji yang pernah disampaikan ketika kondisi dan situasi sudah berubah. Dalam kultur masyarakat Aceh, pepatah tersebut sering dikonotasikan dengan "janji ureung meulaot".13

12 C.F Andrain, Kehidupan Politik dan Perubahan Sosial (Yogyakarta: PT. Tiara Wacana, 1992).

13 Janji ureung meulaot (janji orang yang berprofesi sebagai pelaut -terj). Terdapat sebuah "cerita rakyat" dalam kultur masyarakat Aceh yang kemudian menjadi inspirasi lahirnya pribahasa tersebut. Ceritanya bermula ketika ada sebuah boat pelaut yang tengah terombang-ambing di lautan lepas akibat hempasan badai dan hujan yang luar biasa. Dalam kondisi tersebut, awak kapal ramai-ramai mengucapkan nazar (janji), jika seumpama mereka selamat sampai di daratan, mereka akan bersedekah seekor kerbau untuk fakir miskin. Namun, ketika badai mulai reda, mereka merubah nazar menjadi seekor kambing. Kemudian, ketika daratan sudah mulai terlihat dan badai telah berlalu, mereka mengatakan hanya bernazar dengan seekor ayam, hingga akhirnya ketika sudah tiba dengan selamat di darat, lantas nazar yang tadinya dijanjikan di tengah laut, tak kunjung juga ditunaikan. Mereka melupakannya begitu saja, layaknya badai yang juga telah berlalu. 
Harus diakui, semasa GAM aktif sebagai pihak yang dianggap sparatis oleh Indonesia, mereka tidak bisa bertahan hanya dengan mengandalkan pasukan lapangan yang berjumlah 5000-an14 orang dengan persenjataan dan logistik yang serba terbatas. Lantas, mengapa GAM sanggup berperang hingga puluhan tahun (1976-2005), tentu saja institusi-institusi lain di luar organisasi tersebut ikut membantu dan terlibat dalam "perjuangan" sesuai dengan kapasitasnya masing-masing15, terkhusus institusi masyarakat. Akan tetapi, kala kondisi sudah berubah, di mana sebagian elite GAM telah menjadi kaum elite baru yang diakui Negara, ternyata keadilan dan kesejahteraan yang pernah didengungkan dulu masih dipertanyakan oleh masyarakat Aceh.

\section{Melawan Dengan Kata: Resisten Berwujud Insinuasi}

Dalam sebuah kesempatan gotong royong massal yang diadakan di sebuah desa, saya menyempatkan diri untuk berdiskusi dengan beberapa warga. Di sela-sela membersihkan pekarangan Mesjid, saya kerap menanyakan persepsi mereka terhadap kuasa para elite yang sedang berlangsung saat ini. Dari mulut mungil Mus16, saya menangkap kalimat indah yang terdengar bak pantun, akan tetapi isinya menggambarkan bagaimana cara ia melihat para mantan kombatan yang sudah berkuasa saat ini. Ia mengatakan "Mulia langai watee meu-ue blang, perlei keu umpang oh taboeh padee.

14 Menurut Machfud MD, ketika ia menjabat Menteri Pertahanan Pemerintah Republik Indonesia jumlah militer GAM terdiri atas 4.869 personel. Dari jumlah tersebut, 804 personel dididik di Libia dan 115 personel dilatih di Moro, Filipina. Lihat: www.intelijen.co.id, edisi N0.2/Tahun VIII/Februari 2011.

15 A. Missbach, Politik Jarak Jauh Diaspora Aceh: Suatu Gambaran tentang Konflik Separatis di Indonesia (Yogyakarta: Penerbit Ombak, 2012).

16 Mus (nama inisial, 53 tahun), tinggal di Kecamatan Krueng Barona Jaya, Aceh Besar. 
Peurlee keu rakyat watee nanggroe prang, lheuhnyan lagee glang bak mata kawee". Lebih lanjut, Mus menjelaskan, para mantan pejuang GAM yang hari ini sudah berada di tampuk kekuasaan sudah terlena dengan apa yang dicapai, sehingga begitu mudah melupakan rakyat yang padahal semasa konflik dulu menjadi "tulang punggung" perjuangan.

Kalimat "Mulia langai watee meu ue blang, perlei keu umpang oh taboeh pade",17memiliki makna bahwa, "rakyat" hanya diibaratkan bagaikan langai dan umpang (goni), yang hanya akan bernilai ketika dibutuhkan; langai akan berguna ketika awal mula turun ke sawah untuk membajak, sementara goni diperlukan ketika musim panen tiba untuk menyimpan padi. Pernyataan tersebut semakin dipertegas dalam kalimat selanjutnya, yaitu "peurlei keu rakyat watee nanggroe prang, lheuhnyan lage glang bak mata kawee"18. Ketika perang, perjuangan selalu mengatasnamakan "kita", yang di dalamnya adalah "GAM + rakyat". Sementara ketika damai telah tersemai, GAM memiliki jalan hidup sendiri dan rakyat juga demikian.

Bagi Mus, "masa perang" diibaratkan "musim sawah", sementara "langai dan goni" diibaratkan dengan "rakyat". Setelah "musim sawah" selesai, langai akan disimpan di tempat tertentu dan baru akan dilirik lagi ketika musim turun sawah kembali tiba. Begitu juga dengan goni, saat musim panen padi tiba, ia akan bernilai tinggi di mata para petani, namun kembali tak dilirik manakala prosesi panen telah selesai. Begitupun dengan rakyat, yang dibiarkan

17 Langai hanya akan bermakna ketika membajak sawah, begitu pun goni yang hanya diperlukan ketika hendak menyimpan padi-terj. Langai adalah alat traktor tradisional yang digunakan masyarakat Aceh untuk membajak sawah, biasanya ditarik dengan menggunakan tenaga kerbau atau lembu.

18 "Pada saat perang membutuhkan rakyat, setelah perang dan negeri aman, posisi rakyat bagaikan cacing diujung kail”-terj. 
menggeliat melawan getir hidup dengan sendirinya, persis bagaikan cacing diujung kail yang siap diterkam oleh ikan pemangsa. Rakyat baru akan kembali didekati ketika musim pemilu datang. Selepas musim "panen suara" berlalu, rakyat kembali dibiarkan menggeliat tak menentu.

Selain cerita di atas, saya juga banyak menemukan ungkapanungkapan kekecewaan senada ketika saat berada di warung kopi. Dalam suasana canda ala warung kopi, kita bisa dengan mudah menemukan pola resisten dalam bentuk verbal yang berupa menyindir, mengejek, dan menggosip kaum elite baru Aceh yang sekarang sudah suskses secara ekonomi dan politik. Pola resisten dalam bentuk insinuasi masyarakat bukan semata-mata karena merasa iri terhadap harta yang mereka miliki saat ini. Namun bagi Mus, perilaku semacam itu dianggap sebagai bentuk pengkhianatan terhadap rakyat.

Di sudut yang lain, Zul19, seorang warga Banda Aceh juga menyinggung perihal janji-janji politik yang pernah disampaikan, misal janji pemberian "satu juta per KK" yang pernah diucapkan pasangan Zaini Abdullah - Muzakkir Manaf dalam kampanye pemilihan gubernur 2012 yang katanya akan diberikan kepada seluruh penduduk Aceh jika mereka terpilih. Namun hingga kini, janji itu tak kunjung terealisasikan. Dengan sedikit menggerutu, Zul mengatakan bahwa yang cocok untuk motto awak nanggroe adalah "Tapubloe nanggroe ngeun MoU, Mita breuh mirah ngeun UU PA".20

Cerita di atas hanya sebagian dari sikap perlawanan yang terjadi di belakang layar atau apa yang disebut Scott sebagai hidden transcript. Sebagian dari para "pembenci" tidak berani meluapkannya

19 Zul (inisial, 30 tahun), tokoh pemuda, tinggal di Banda Aceh.

20 “Menjual negeri dengan MoU, dan mencari nafkah dengan UU PA). Hal ini diungkapkan Zul karena 'dagangan politik' orang GAM selalu menyebut bahwa 'kami akan berjuang untuk UU PA dan MoU Helsinki'”. 
secara terang-terangan. Apa yang terjadi ini bisa dibandingkan dengan apa yang ditulis Scott sebagai berikut:

"Elite lokal hampir selalu menang dalam kehidupan ekonomi kampong. Dengan memperhatikan penguasaannya atas sumber-sumber daya, elite pada umumnya juga mengendalikan kehidupan ritual publik -yaitu, tingkah laku "di atas pentas" dari kebanyakan orang miskin yang terdapat di masyarakat itu. Hanya "di belakang pentas", di mana gossip, hujatan, fitnah, dan sabotase yang secara terselubung mengejek dan membantah tatanan ritual publik, maka disanalah kontrol kaum elite tidak berlaku lagi..."21

\section{Kaos “SATU JUTA Per KK”: Bentuk Resistensi Terbuka}

Bagi masyarakat kalangan akar rumput, resistensi terhadap kaum elite terjadi di belakang layar, berbeda dengan yang dipraktekkan oleh Helmy22, yang berani melakukannya secara terang-terangan. Helmy adalah seorang pengusaha di Banda Aceh. sebagai masyarakat Aceh, ia merasakan ketidaknyamanan dengan segala hegemoni awak nanggroe yang terjadi. Sehingga ia pun melakukan perlawanan dengan gayanya sendiri. Salah satunya dengan mendesain kaos yang bertuliskan "SATU JUTA per KK" di bagian depan kaos yang kemudian dipasarkan di Aceh.

Helmy memanfaatkan media sosial facebook dan twitter sebagai media promosi. Sepertinya, ia mengamalkan betul apa yang dikatakan mantan presiden Indonesia Soesilo Bambang Yudhoyono "Setiap krisis megandung peluang". Kini, kaos buatannya tidak hanya

21 J. Scott, op.cit.,

22 Helmy, pengusaha, tinggal di Banda Aceh. 
laku di wilayah Aceh, namun juga dipesan oleh masyarakat Aceh yang ada di luar di luar negeri, semisal Inggris, Denmark, dan lain-lain.

Baginya, pembuatan kaos tersebut bukan hanya semata-mata perkara bisnis, akan tetapi juga sebagai bentuk kontrol sosial terhadap pemerintah. "Tujuannya ya... untuk mengingatkan pemerintah apa yang pernah dijanjikannya. Banyak orang menganggap saya sedang berbisnis. Cuma kalau saya gratiskan, ya...tidak mungkin juga. Saya butuh modal untuk bikin kaos", tegas Helmy. Semakin banyak yang memakai kaosnya, maka akan semakin banyak pula yang sadar akan janji politik penguasa. Bagi Helmy, motivasi terbesar hingga melahirkan ide menciptakan kaos tersebut adalah melawan hegemoni rezim Pemerintah Aceh yang menurutnya sudah jauh menyimpang dari garis perjuangan. Terlebih saat ini hanya sedikit golongan masyarakat yang berani muncul secara terang-terangan untuk mengontrol penguasa. Ia menjelaskan bahwa:

"hegemoni rezim itu harus dilawan, apalagi saat ini minim perlawanan, mahasiswa juga mandul dalam merespon realitas sosial saat ini. Kaos ini memang saya jual, mengapa saya jual? Karena saya tak punya cukup uang untuk mengorganisir demonstrasi di tengah masyarakat yang kesulitan ekonomi dan mahasiswa yang minim militansi. Saya selalu mensyaratkan kepada siapa pun pembeli kaos supaya ketika memakainya harus memfoto, lalu menguploadnya di media sosial agar kampanyenya semakin meluas. Dengan itu, setiap orang bisa demo kapan pun mereka mau. Dan juga supaya setiap pembeli itu sadar bahwa mereka bukan hanya sekedar membeli kaos, tetapi juga bergabung dalam revolusi... harapan kita, dengan begitu semoga bisa mengubah kondisi yang sudah begini parah"

Keberadaan kaos tersebut sangat kontroversial di masyarakat, bahkan ada yang mengatakan Helmy sedang mencari sensasi, namun dengan bermacam kontroversi yang muncul, justru semakin membuat kaos itu kian terkenal yang membuatnya sudah laku terjual mencapai 
angka 1000 potong. Diterimanya kaos di masyarakat yang bisa dilihat dari angka jual yang mencapai 1000 potong menjadi tanda bahwa masyarakat sebenarnya juga merasakan hal yang sama, yaitu ingin menagih janji yang pernah disampaikan oleh pemerintah dalam kampanye. Masyarakat ingin mengeskpresikan kegeramannya dengan ikut "berkampanye" melalui kaos tersebut.

\section{Resistensi dan Kegagalan Resiprositas Kaum Elite}

Pertunjukan politik dan tata kelola daerah yang tidak puas dari para elite, monopoli akses terhadap sumber daya dan hegemoni kekuatan politik dan ekonomi yang dipraktekkan memunculkan ketidakpercayaan publik (public distrust). Distrust ini menimbulkan disorientasi yang pada gilirannya berpeluang melahirkan pembangkangan (disobedience) dan resistensi. Dalam bahasa Gurr dijelaskan telah terjadi perampasan (deprivation) terhadap hak yang seharusnya dimiliki oleh rakyat ketika nilai-nilai kesejahteraan (welfare values) yang dijanjikan oleh pemegang otoritas tidak terealisasi sebagaimana mestinya.23 Padahal, pasca perdamaian, begitu banyak dana reintegrasi yang mengalir ke Aceh, hanya saja yang terjadi di lapangan sarat dengan manipulasi dan beragam kepentingan. Kondisi ini dipertegas oleh Fuad M, mantan aktivis 1998 yang sekarang aktif di Lembaga Aceh Institute yang mengatakan bahwa:

"Aceh ini aneh sekali. Dulu konflik dengan Jakarta karena tidak ada uang, sekarang setelah banyak uang, konfliknya semakin parah, orang Aceh sudah berperang sesama orang Aceh. Pasca damai, banyak sekali dana yang mengalir ke Aceh, ada dana reingtegrasi, ada dana diyat, apalagi damai Helsinki itu selepas Tsunami, dana-dana dari donator begitu banyak... sekarang, dengan posisi Aceh sebagai daerah otonomi khusus,

23M. Manan, ibid. 
dana Otsus situ triliunan. Tapi, ya itu... makin banyak uang, makin kuat kita berperang (sesama Aceh)”.24

Bentuk resistensi ini bisa dilihat dalam dua sudut pandang, yaitu sudut pandang politik dan sudut pandang sosial-antropologis. Sudut pandang politik ditandai dengan fenomena kuatnya resisten dan kontrol masyarakat terhadap elite (Negara) atau terhadap kekuatan politik tertentu, sementara sudut pandang sosialantropologis tercermin dari reaksi masyarakat dan fenomena anarkis yang lahir dari akar rumput, kemudian juga tergambar dari konflik horizontal.25

Perlawanan yang hadir, baik dalam bentuk insinuasi maupun dalam aksi nyata, tentu saja tidak bisa dipisahkan dari adanya "kepentingan-kepentingan" di balik itu semua. Bisa jadi, seseorang yang mengejek atau menggosip para elite baru itu karena ia jauh atau tidak termasuk dalam golongan yang mendapatkan "kue kekuasaan" atau para "barisan sakit hati" yang jauh dari akses mendapatkan "hasil perjuangan". Tentu saja, dengan berbagai perspektif yang tumpang-tindih, kita akan sulit untuk melihat kejadian-kejadian tersebut sebagai sebuah sikap perlawanan ataukah hanya aksi kecil yang sifatnya incidental dan gejala sekunder suatu aksi kejahatan.26. Namun, jika merujuk pada apa yang disampaikan Scott, kita akan yakin bahwa itu adalah sebuah sikap resistensi:

"Menuntut agar perlawanan kelas-kelas yang selalu kalah itu "berprinsip" atau "tanpa pamrih", tidak hanya merupakan ilusi yang terlalu muluk dan pengingkaran terhadap status moral dari kebutuhan material fundamental; malah lebih dalam lagi, ia lebih merupakan salah satu konstruksi dasar perjuangan

24 Fuad Mardhatillah, mantan aktifis dan akademisi, tinggal di Darussalam, Banda Aceh.

25 M. Manan, ibid.

26 J. Scott, ibid. 
kelas yang pertama, dan terutama merupakan petarungan untuk mendapat kesempatan kerja, produksi, harta milik dan pajak. Masalah-masalah "roti dan mentega" merupakan hakekat politik kelas bawah dan perlawanannya. Dari perspektif ini, konsumsi merupakan tujuan, maupun hasil dari perlawanan dan kontra-perlawanan"27

Sistem politik akan memiliki legitimasi yang luas manakala mampu manyatukan keanekaragaman kelompok ke dalam organisasiorganisasi dan keyakinan-keyakinan politik yang sama. Dalam hal ini, bagaimana organisasi politik pemerintahan mampu menyediakan peluang-peluang, akses, serta kesempatan yang sama bagi kelompok primordial dan ekonomi yang berbeda untuk berperan serta dalam lingkaran organisasi tersebut. Sehingga semua kelompok akan merasa bahwa mereka adalah bagian dari identitas bersama dan semua akan ikut serta dalam sistem distribusi.28 Kondisi semacam ini yang masih gagal dilakukan oleh elite baru yang berkuasa di Aceh. Pupusnya impian yang pernah digantungkan masyarakat Aceh pada awak nanggroe melahirkan bencana kemanusian baru yang dipraktekkan melalui ragam bentuk resistensi.

Biasanya, masyarakat akan memasang wajah manis di hadapan para elite, namun penuh sumpah serapah ketika di belakangnya. Dalam bahasa Scott, relasi semacam ini diistilahkan sebagai hidden transcript. Seakan, relasi antara kedua pihak ini tercipta dari duri dan besi karatan. Sementara bagi masyarakat yang memiliki power, upaya-upaya perlawanan dilakukan secara terbuka dan terang-terangan, misalnya apa yang dilakukan oleh Helmy dengan menciptakan baju kaos berdesain "peringatan" terhadap pihak penguasa. Geliat perlawanan-perlawanan di atas terbaca sebagai respon atas ketidaknyamanan dan kegagalan resiprositas penguasa.

27 Ibid.

28 C.F Andrain, ibid.

\section{2 | Iromi Ilham}


Stressing pointnyaadalah adanya sharing kesejahteraan yang tidak merata di kalangan masyarakat Aceh. Ini ibarat api dalam sekam yang sewaktu-waktu dapat menghancurkan perdamaian Aceh. Jika dulu masyarakat percaya akan propaganda Nyoe keun ie mandum leuhob, nyoeu keun droe teuh mandum gob, kini melahirkan antitesis baru; Nibak ngeun ie, mangat ngeun leuhob, nibak ngeun droeuteuh, mangat that ngeun gob (lebih baik dipimpin oleh "orang lain", ketimbang dipimpin "orang sendiri”).

\section{PENUTUP}

Kondisi ini harus menjadi refleksi bagi kalangan elite baru Aceh. Ternyata masih ada yang keliru dalam cara membangun pranata sosial pasca MoU Helsinki. Tafsir perdamaian dan kesejahteraan harus ditinjau kembali. Refleksi terbesar yang seharusnya muncul adalah tentang hakikat kemanusiaan. Jusuf Kalla -sang inisiator perdamaian Aceh- ketika membahas isu perdamaian di tingkat nasional dan internasional selalu berbicara di atas logikalogika kemanusiaan. Karena hakikat transformasi adalah melahirkan kaum elite yang mampu menjadi panutan, dapat mengayomi dan melindungi rakyat, bukan kaum elite yang penuh intrik traksasional yang hanya mementingkan bagaimana menguasai dan mempertahankan kekuasaan.

Kekuasaan elitis di Aceh yang saat ini mayoritas berada di tangan mantan GAM harus mampu memperhatikan hal-hal yang menjadi pemicu lahirnya konflik di masyarakat, khususnya terkait dengan "isi perut" yang secara historis juga melatarbelakangi konflik politik Aceh dengan Pemerintah Indonesia.

Betapa mudahnya kita melupakan masa lalu itu tanpa mau berguru. Transparansi publik dalam mengelola kekayaan Aceh dan jaminan penegakan hukum adalah kunci menuju perdamaian hakiki dan bisa melewati tahap-tahap perdamaian yang masih rentan (peace vulnerabilities). Hanya dalam negara yang aman dan kehidupan yang 
damai, hak-hak sosial, ekonomi, politik dan budaya bisa dinikmati. Jika tidak demikian, posisi elit kembali akan terganggu dan menjadi sasaran sikap resisten masyarakat, yang pada gilirannya kembali menegaskan akan kebenaran ungkapan Vilfredo Pareto, sang teoritikus politik; sejarah merupakan suatu perkuburan aristokrasi.

\section{DAFTAR PUSTAKA}

Abdullah, I., 2002. 'Tantangan Pembangunan Ekonomi dan Transformasi Sosial: Suatu Pendekatan Budaya”, Jurnal Humaniora, XIV (3).

Andrain, C.F., 1992. Kehidupan Politik dan Perubahan Sosial. Yogyakarta: PT. Tiara Wacana.

Aspinall, E., 2007. 'The Construction of Grievance: Natural Resources and Identity in a Separatist Conflict", Journal of Conflict Resolution.

Evers, H. D \& Schiel, T., 1990. Kelompok-Kelompok Strategis: Studi Perbandingan tentang Negara, Birokrasi, dan Pembentukan Kelas di Dunia Ketiga, Jakarta: Yayasan Obor Indonesia.

Manan, M., 2005. Gerakan Rakyat Melawaan Elite, Yogyakarta: Resist Book.

Missbach, A., 2012. Politik Jarak Jauh Diaspora Aceh: Suatu Gambaran tentang Konflik Separatis di Indonesia, Yogyakarta: Penerbit Ombak.

Scott, J., 2000. Senjatanya Orang-Orang Yang Kalah: Bentuk Perlawanan Sehari-hari Kaum Tani, Jakarta: Yayasan Obor Indonesia.

Sulaiman, M. I., 2000. Aceh Merdeka: Ideologi, Kepemimpinan, dan Gerakan, Jakarta: Pustaka Al-Kausar. 
Varma, SP., 2010. Teori Politik Modern, Jakarta: PT Raja Grafindo Persada.

http://aceh.tribunnews.com/2014/08/21/generasi-helsinki-rentantersingkir 